\title{
Monitoring of Heavy Metal Pollution in Water and Sediments at the Mid-Black Sea Region by Using Passive Sampling Method Diffusive Gradients in Thin Films
}

\author{
Arife Şimşek ${ }^{1, a, *}$, Şule Sancak ${ }^{2, b}$, Gülfem Bakan ${ }^{2, c}$ \\ ${ }^{1}$ Blacksea Advanced Technology Research and Application Center, Ondokuz Mayls University, 55270 Samsun, Turkey. \\ ${ }^{2}$ Environmental Engineering Department, Faculty of Engineering, Ondokuz Mayls University, 55139 Samsun, Turkey.
} *Corresponding author

\section{A R T I C L E I N O A B S T R A C T}

Research Article

Determining the potential bioavailability of heavy metals, evaluating according to adapted regulations is essential to efficiently conserve our coastal and estuarine waters. In this study, it is aimed to determine the industrial pollution and various other pollution sources that the Black Sea Basin is exposed to by using DGT (Diffusive Gradients in Thin Films) method and grab (manuel)

Received : 19/01/2021

Accepted : 13/04/2021 sampling method in water and sediment and to evaluate the existing pollution according to quality standards. In Samsun, seasonal samples were collected from five different sampling stations, namely Akkiraz Stream, Hıdırellez Stream, Organized Industrial Zone (OIZ) Channel, Şabanoğlu Stream and Selyeri Stream, which are selected from Tekkeköy region where industry is intensively active. In order to determine the heavy metal content in both water and sediment samples, the DGT

Keywords:

Diffusive gradients in thin films

Heavy metal

Mid-Black Sea

Passive sampling

Sediment method was chosen for passive sampling and the grab sampling method was used for active sampling, and the efficiency of the methods was evaluated. According to the results of the study, the heavy metal concentration in grab sampling for water samples in descending order $\mathrm{Al}>\mathrm{Fe}>\mathrm{Zn}>$ $\mathrm{Pb}>\mathrm{Ni}>\mathrm{Cu}$; In the samples taken with $\mathrm{DGT}$, they are listed as $\mathrm{Al}>\mathrm{Fe}>\mathrm{Zn}>\mathrm{Cu}>\mathrm{Ni}>\mathrm{Pb}$. There were significant relationships between the total metal concentrations of sediment (Csed) and water $(\mathrm{Csu})$ in grab sampling and metal concentrations sediment (Csed-DGT) and water (Csu-DGT) measured by DGT. It was found that the sensitivity and performance of sampling with DGT was 210 times higher compared to grab sampling. The high resolution in situ DGT technique for the assessment and management of the potential release risk of heavy metals at the water-sediment

interface is a complementary method that contributes to the standard grab sampling method.

\section{Introduction}

The Black Sea is the world's largest inland sea surrounded by land. Almost a third of the entire land area of the European continent flows here, and in the last 50 years, the Black Sea region has experienced a serious degradation from water-borne waste from 17 countries. Irregular and unplanned withdrawal of fresh water for irrigation, hydro and thermal power generation, use of coastal areas for construction, and a large number of untreated industrial and agricultural wastes discharged into rivers dumped into the sea all have detrimental effects on health. The severe degradation it is facing now can be explained by a variety of factors ranging from high pollution loads from rivers discharging into the sea, to inappropriate policies and poor management practices (Bakan and Büyükgüngör, 2000; Akbal et al., 2011).
In recent years, unmanaged fishing, intensive transport activities, mining activities and the discharge of toxic wastes have started to become contaminated. Large amounts of domestic wastewater and industrial wastewater are transported by rivers and discharged into the Black Sea. As a result, organic and inorganic contaminants accumulate here. These pollutants entering the aquatic ecosystem may not directly harm organisms, but aquatic organisms through the food chain can also threaten people's health (Bat et al., 2013).

Contamination of aquatic ecosystems with nutrients (synthetic) organic compounds and heavy metals and their consequences on human health and biodiversity conservation are important topics of debate among environmental scientists (Jitar et al., 2015). In Turkey, as in the world about this topic are also carried out several 
studies (Türkmen et al., 2018; Mutlu and Kurnaz, 2018; Canpolat et al., 2020; Tokatli and Ustaoglu, 2020; Aydın et al., 2021). The aquatic environment is very sensitive to metal contaminants and therefore metals are considered critical contaminants. In addition, metals have the potential to pollute sediment and water, which can be dispersed by the effect of tides (Alkan et al., 2015). Along with water, sediments play an important role as the most important sources of storing pollutants as well as possible future sources and carriers of pollutants. Since pollutants released into water tend to accumulate in sediment, water and sediment should be handled in an integrated manner when monitoring pollution (Bakan, 2000). Pollutants that accumulate in the bottom sediments can be stored in the food chain as a result of physical, chemical and biological processes, or they can be released and pass into the water layer above the sediment (Bakan, 1995). There are many studies on water quality monitoring in our country, but these studies are for research purposes. Studies on pollution monitoring and follow-up are not sufficient. Therefore, chemical monitoring is not carried out according to the Water Framework Directive (WFD). Since chemicals in sediment will also affect water quality, sediment should be included in water quality monitoring programs.

Sediments contaminated with heavy metals have the potential to affect life in streams and rivers and then inhibit the recovery of the ecological state. In rivers affected by many industrial, agricultural studies, metals tend to be very strongly associated with sediment, and this trend means that metal-rich sediments do not easily release associated metals. Therefore, unless sediments are removed by the strong water flow to replace less metal-contaminated sediments, they remain metal-rich for long periods of time and have long-term potential ecotoxicological interactions with biota (Jones et al., 2017).

In this study, the current pollution situation in the Black Sea is discussed with the passive sampling method DGT, which brings a new perspective to standard monitoring methods. The DGT device consists of a circular container made of plastic and with a reciprocating and perforated (DGT window) snap fit. A binding gel, spreading gel, and filter membrane are stacked on the plunger and placed in the cap assembly. Normally, the dimensions of the device ensure that the two gels and the filter membrane are sealed when the cap is attached. The dimensions of the layers vary depending on the characteristics of the environment such as the flow rate of the sampled water (Zhang, 2003). Figure 1 shows the DGT and its parts used in water and sediment. DGT is a passive sampling and measurement technique used in environmental chemistry for the determination of elements and compounds in aqueous environments including natural waters, sediments and soils. Suitable for in situ detection of biologically present toxic trace metal contaminants. For metals / metalloids, DGT passive samplers are recommended to be used in various assessments as a monitoring tool to complement the information obtained by active (grab) sampling (Allan et al., 2008; Hanke et al., 2009). This technique requires a specially designed passive sampler containing a binding gel, spreading gel, and membrane filter (Zhang and Davidson, 1999). a)
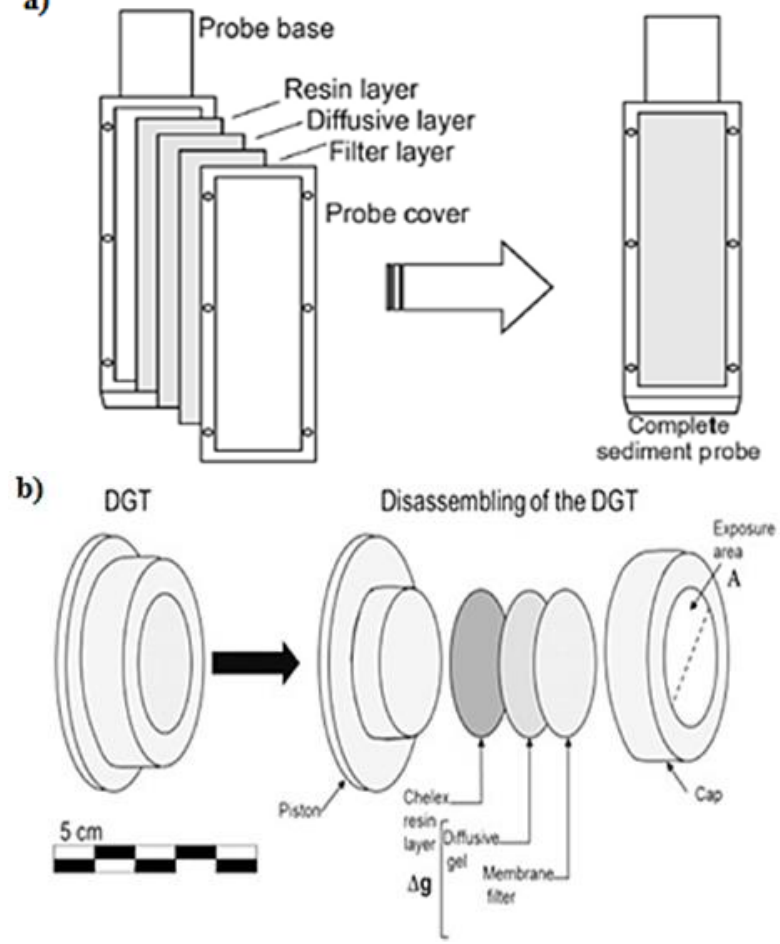

Figure 1. a) DGT and its parts used in sediment b) used in water (Budasheva et al., 2019; Chaudhary et al., 2020)

The element or compound passes through the membrane filter and diffusive gel and is rapidly assimilated by the binding gel. Post-dispensing analysis of the binding gel can be used to determine the bulk solution concentration of the element or compound in a simple equation. After DGT devices are acquired, binding gels can be separated using methods that bind the target analyte and the DGT binding gel. The eluent can then be analyzed quantitatively by a range of analytical techniques such as ICP-MS, ICP-OES, AAS, UV-VIS spectrometry, or its density can be measured by computer imaging (Davison et al., 2000).

DGT, which has been in development since 1994 (Davison and Zhang, 1994; Zhang and Davison, 2015; Menegário et al., 2017), has many advantages described in the literature:

- Determination of the time-weighted average concentration provides a better representation of the contamination in time;

- The accumulation of target element in the instrument increases analytical sensitivity;

- In situ fractionation leading to DGT-unstable fraction measurement is considered to be a more biologically relevant fraction than the dissolved fraction (Rougerie et al., 2021).

DGT measures all organic species and variable inorganic species. These are forms that can be used biologically. Inorganic species in solution can be measured separately from organic species using different types of gels for the diffusive layer. When used in water it measures unstable species and DGT can be used in almost all natural waters. It is the ideal environment for sea water and most fresh water uses (Zhang et al., 1995; Davison et al., 2000). 
The aim of this study is to determine the water and sediment samples in Tekkeköy District of Samsun Province in Middle Black Sea Region; I. Use the DGT technique as a passive sampling methodology for in situ determination of biologically usable fractions of heavy metals in a highly dynamic estuarine environment; II. To investigate its usability according to the active sampling method, grab sampling; III. To determine the performance and reliability of the DGT technique.

\section{Materials and Method}

\section{Study Area}

Industrial establishments in the Samsun-Tekkeköy region, which are chosen as the study area, cause significant environmental pollution, thus agricultural products, forests, ecosystem and human health are negatively affected by pollution. For the analysis, the sampling points of Akkiraz Stream (S1), Şabanoğlu Stream (S2), OIZ (Organized Industrial Zone) Channel (S3), Hidirellez Stream (S4) and Selyeri Stream (S5) discharged into the Black Sea were selected (Figure 2).

Akkiraz Stream (S1) is exposed to pollution due to the debris and deposits coming from the upper basins continuously and it is in danger of flooding because of narrowing of the bed section. For this reason, it is recommended to clean the stream bed regularly. Due to the abundance of metal and mining enterprises in the regions where Şabanoğlu Stream (S2) and Hıdırellez Stream (S4) are located, many sources of pollution are discharged to these points. In the OIZ Channel (S3), there are a total of 111 industrial parcels, 98 of these parcels are in production, 12 of these are in construction and 1 of these is in the project phase. Since the production wastes of all these industrial establishments are given to the OIZ Channel, they constitute a serious source of pollution. In Selyeri Stream (S5), the stream bed should be cleaned regularly and also upper basin measures should be taken such as reverse weir, flood trap, bridle, bench, afforestation (URL-1).

\section{Sampling and Analysis}

Sampling started in September 2017 and samples were collected for three seasons in total, in December 2017 and April 2018, respectively. In order to determine the pollutant loads of the five selected sampling points, especially land based, sediment samples were collected with the EkmanBirge sediment sampler and water samples were collected with a nansen bottle. Sterile plastic containers were used to carry out physicochemical analysis of the samples collected in sediment, and plastic pipes in the form of columns with a diameter of $10 \mathrm{~cm}$ and a sediment depth of approximately 10 $\mathrm{cm}$ were used for DGT analyses.

For sediment samples brought to the laboratory under appropriate conditions, the solid / liquid ratio of 1/5 was waited for about 1 hour and the $\mathrm{pH}$, redox potential (Eh$\mathrm{mV})$, electrical conductivity $(\mathrm{EC}-\mu \mathrm{s} / \mathrm{cm})$, water content $\%$, organic matter content $\%$ and particle size analyses were made. Approximately 15-20 gr of sediment samples were taken for wet analysis of sediment, and water content was determined by drying in an oven at $103^{\circ} \mathrm{C}$ for 12 hours. In the determination of the grain size, the wet sediment was dried in an oven and the sediment amount below $500 \mu \mathrm{m}$ $>250 \mu \mathrm{m}>125 \mu \mathrm{m}>90 \mu \mathrm{m}>63 \mu \mathrm{m}$ was determined with the Fritsh-Analysette 3 automatic vibrating sieve. Before and after the drying process, the sediment samples taken were weighed and the water and organic matter content $\%$ were determined.

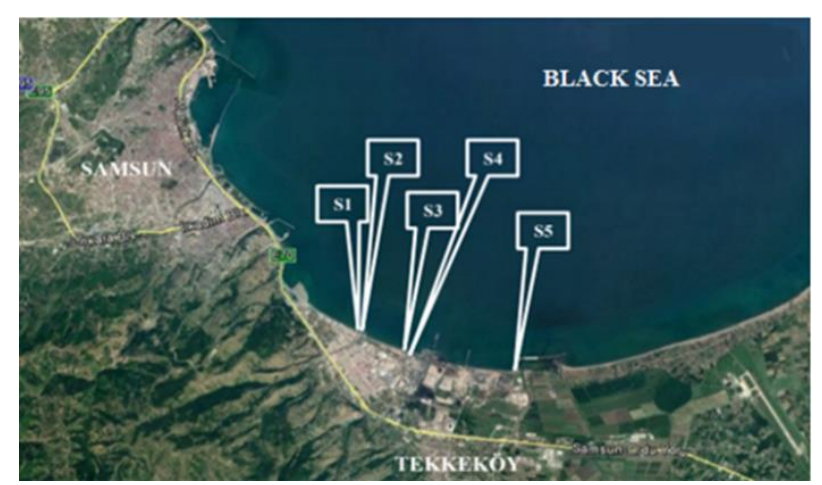

Figure 2. Sampling points at Mid-Black Sea Region Samsun - Tekkeköy (Turkey)

\section{DGT Analysis}

In the DGT analyses on water samples, the samples collected in September 2017 and April 2018 were selected and metal analysis was performed for two seasons in total. The reason why samples taken from three periods were studied for only two seasons for water; In the samples taken in December, the metal concentrations in the water are below the measurement limit for many metals. According to the DGT method, which was planned to be applied under laboratory conditions, the following steps were followed before the analysis was performed;

- $2 \mathrm{~L}$ of water sample was placed in $3 \mathrm{~L}$ plastic containers, $20 \mathrm{ml}$ of $1 \mathrm{M} \mathrm{NaNO}_{3}$ solution prepared previously was added.

- $\quad$ The LSPM-NP coded DGT devices were placed in this immersion solution, parallel to the walls of the container and in the middle of it. Time and sample temperature were noted at the time of insertion. During and after immersion of the DGT devices, it must be ensured that the solution is thoroughly mixed but that there is no cavitation (Zhang and Davison, 1995) (Figure 3).

- Approximately 4 hours later, the time and sample temperature were noted again, DGTs were removed from the solution and the surface was washed with distilled water.

- For analysis, the DGT devices were turned on, Chelex gels inside were taken into separate centrifuge cups for each sample, and $1 \mathrm{ml} 1 \mathrm{M} \mathrm{HNO}_{3}$ was added to it and was ready for analysis after 24 hours (Zhang et al., 1998).

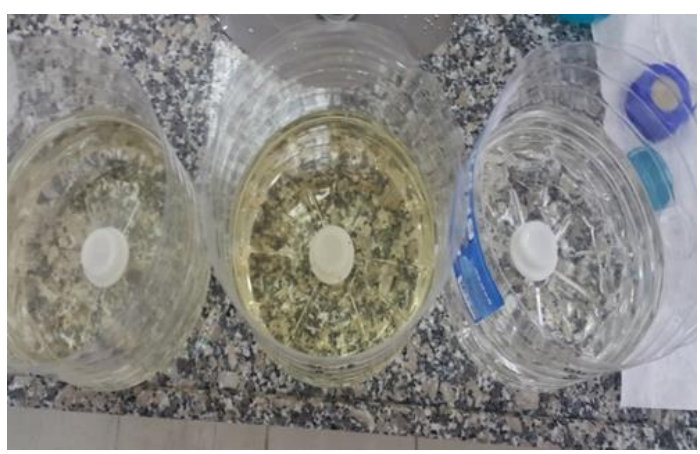

Figure 3. DGT application to water samples 
After these procedures were applied, ICP-MS (Inductively coupled plasma mass spectrometry) device was used for metal analysis of a total of ten samples collected in September 2017 and April 2018 and the metal analysis results in DGTs were evaluated on the basis of SWQR (Surface Water Quality Regulation, 2016). For the DGT analysis of sediment samples, sampling points with the highest pollution in all three seasons were selected. DGT was applied to all sampling points except S4 from the samples collected in December 2017, and to the S5 sampling point for the samples collected in September 2017 and April 2018. Since the samples taken from the S4 sampling point gelled, the analysis result could not be obtained. For this reason, the $\mathrm{S} 4$ point is not included in the results section of the analysis results. For other analyses, the S5 point, which was determined to be more polluted in total metal analyses, was chosen because there were not enough DGT probes in April and September. The following steps were followed before the analysis was carried out;

- While the LSPM-NP coded DGT probes are placed in the sediment, they are marked to leave a $2-3 \mathrm{~cm}$ gap from the top.

- $\quad$ DGT probes were pushed as deep as possible, slowly and evenly, just in the middle of the sediment samples enclosed in the column, temperature and time were noted (Figure 4).

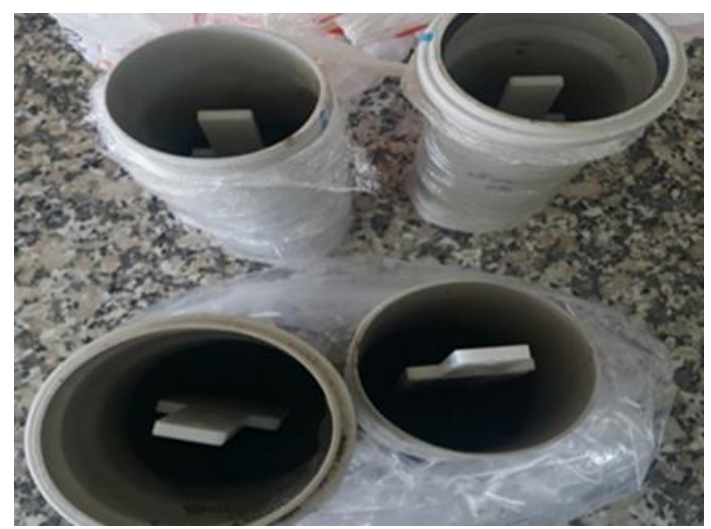

Figure 4. DGT application to sediment samples

Table 1. Cutting intervals of DGT gels applied to sediment samples

\begin{tabular}{l|cc}
\hline \multicolumn{1}{c|}{ Time } & Sample & Cutting intervals of gels (cm) \\
\hline December & S1 & $0.5-0.5-1-1-1-2-2-2-2$ \\
December & S2 & $0.5-0.5-1-1-1-2-2-2-2$ \\
December & S3 & $0.5-0.5-1-1-1-2-2-1$ \\
December & S5 & $0.5-0.5-1-1-2-2-2$ \\
September & S5 & $0.5-0.5-1-1-1-2-2-2-2$ \\
April & S5 & $0.5-1-1-2-2-1.5$ \\
\hline
\end{tabular}

Table 2. 24 samples at different depths selected from the DGT applied sediment samples

\begin{tabular}{c|cc}
\hline Time & Sample & Selected depth $(\mathrm{cm})$ \\
\hline September 2017 & S5 & $0.5-3-4-8-12$ \\
& S1 & $0.5-2-4-8$ \\
December 2017 & S2 & $0.5-2-4-10-12$ \\
& S3 & $0.5-2-4-8$ \\
April 2018 & S5 & $0.5-3-7$ \\
\hline
\end{tabular}

After a 24 hour dwell time, DGT probes were removed from the sediment columns and washed with distilled water. The gels, together with the filter membranes, were carefully removed and placed on a clean surface. By using the special cutting blades that come with the DGT devices, the gels were cut at certain intervals in accordance with the method, as in Table $1.2 \mathrm{ml}$ of $1 \mathrm{M} \mathrm{HNO}_{3}$ solution of $69 \%$ prepared previously was added on each of the DGT gels cut at specified intervals. During this process, it must be ensured that the gel is completely immersed in the acid solution (Devillers et al., 2017).

Among the 48 sediment samples obtained after the gel cutting process, 24 samples at different depths in Table 2 were selected. ICP-MS spectrometer was used for metal measurements in sediment samples. Since there is no criterion for the evaluation of sediment quality in our country, it was evaluated based on the International Sediment Quality Guidelines (SQGs) obtained at the end of this study.

\section{Statistical Analysis}

Correlations between four parameters (Csed, CsedDGT, Csu, Csu-DGT) for statistical analysis were obtained by Pearson correlation coefficient analysis (SPSS 13.0). Sediment data were taken into account as $\mathrm{mg} / \mathrm{L}$ when used in correlation.

\section{Results and Discussion}

\section{Evaluation of Sediment Analysis Results}

$\mathrm{pH}$, electrical conductivity (EC), redox potential (ORP), salinity, water content $\%$, organic content $\%$ and particle size analyzes were performed for sediment samples collected three seasons at the sampling points of Akkiraz Stream (S1), Şabanoğlu Stream (S2), OIZ (Organized Industrial Zone) Channel (S3), Hidirellez Stream (S4) and Selyeri Stream (S5). The sediment analysis results of the seasonal samples are given by calculating the average of the sampling points in Table 3 .

The $\mathrm{pH}$ value in the sediment is used to measure the acidity or alkalinity in the sediment or water column and strongly affects the solubility of heavy metals (Belzile et al., 2004; Guven and Akinci, 2013). A decrease in $\mathrm{pH}$ resulting from release of $\mathrm{H}^{+}$into pore water causes secondary release of heavy metals (Peng et al., 2009). pH is an important variable affecting the biotic composition of the system, and low $\mathrm{pH}$ causes an increase in uptake of toxic elements by non-aquatic organisms (Mutlu, 2019). The instability and bioavailability of heavy metals in the sediment can be affected by the behaviour and physiology of organic matter, sulphides, Fe and Mn oxides, carbonates and organisms (Campana et al., 2013 ; Costello et al., 2015 ; He et al., 2018). Paller et al. (2019) acknowledges redox and $\mathrm{pH}$ as the main factors influencing the instability of pollutants, including heavy metals in the aquatic environment. In our study, it is seen that the average $\mathrm{pH}$ values of the sampling points have basic $\mathrm{pH}$ where heavy metal release is less than acidic $\mathrm{pH}$. Looking at the average $\mathrm{pH}$ values of the sampling points, it is seen that they have basic pH. ORP is accepted to be an important parameter controlling heavy metal mobility in the sediment (De Jonge et al., 2012 a, b; Kalantzi et al., 2013; Kelderman and Osman, 2007; Peng et al., 2009). ORP is a measure of 
electron availability and predicts the stability and bioavailability of heavy metals in sediment or soil. If the oxidative-reductive potential is above zero, namely positive, the sediment is aerobic, if the transition is between 0 and $-200 \mathrm{mV}$, the transition is anoxic, and if it is below $-200 \mathrm{mV}$, the sediment is anaerobic (Rump and Krist, 1988). Accordingly, all sampling points are in transition anoxic sediment state between 0 and $200 \mathrm{mV}$. In the study conducted by Yuan et al. (2020), the DGT method was applied for the sediment water interface under oxic and anaerobic conditions, and it was determined that the concentrations decreased in the oxic state and increased in the anaerobic state. For the anoxic state, they stated that it facilitates the reduction of the reducible fraction of heavy metals and further enhances desorption, replenishment and diffusion in aquatic ecosystems.

According to the electrical conductivity (EC) results in the sediment, the lowest average of $256.62 \mu \mathrm{s} / \mathrm{cm}$ was September 2017, and the highest was $396.60 \mu \mathrm{s} / \mathrm{cm}$, which belongs to the average of sampling points for the period of April 2018. Salinity and dissolved minerals are among the factors that cause increased electrical conductivity (Atıc1, 2004). Accordingly, the lowest salinity is seen in September 2017 and the highest salinity in April 2018 as in EC. As a result of the melting of snow and icing in winter, a higher water content in sediment is observed in summer and spring. Therefore, the lowest water content is seen with $16.12 \%$ in December 2017 (winter).

At the sampling points, the amount of organic matter may vary as a result of domestic and industrial discharges with high organic content. Heavy metals can be released from the surfaces of solid iron and manganese oxides by reductive dissolution or from decomposition of organic matter into pore water (Harper et al., 2000; Sun et al., 2019). Accordingly, high organic matter will increase heavy metal release into the water and sediment environment. When the organic matter is evaluated as the sampling point, the highest content is in the sampling point of the OIZ (Organized Industrial Zone) Channel (S3) and the averages given in Table 3 in April 2018.

\section{Evaluation of DGT Analysis Results}

After the DGT method applied to water and sediment samples, the measurement could not be performed because gelation occurred in the $\mathrm{S} 4$ sample. In addition, $\mathrm{Cd}, \mathrm{Cr}, \mathrm{Mn}$ elements were not taken into consideration when evaluating, since they are below the measurement limit according to the analysis results. In Table 4, the comparison of the DGT analysis results applied to the water samples with the $\mathrm{mg} / \mathrm{L}$ heavy metal values in the Surface Water Quality Regulation (SWQR) (URL-2) is given.

Table 3. Average values of sediment quality analysis results (mean $\pm \mathrm{SD}$ )

\begin{tabular}{l|lccc}
\hline \multirow{2}{*}{ Parameter } & \multicolumn{1}{|c}{ Unit } & September 2017 & December 2017 & April 2018 \\
\cline { 2 - 5 } $\mathrm{pH}$ & \multicolumn{3}{c}{ Average } & $7.69 \pm 0.15$ \\
$\mathrm{ORP}$ & $\mathrm{pH}$ & $7.73 \pm 0.27$ & $7.76 \pm 0.96$ & $-43.82 \pm 11.55$ \\
$\mathrm{EC}$ & $\mathrm{mV}$ & $-45.38 \pm 15.52$ & $-62.88 \pm 46.56$ & $396.6 \pm 268.50$ \\
Salinity & $\mu \mathrm{s} / \mathrm{cm}$ & $256.6 \pm 95.23$ & $309.5 \pm 197.92$ & $0.58 \pm 0.22$ \\
Water content & $\mathrm{g} / \mathrm{L}$ & $0.14 \pm 0.05$ & $0.16 \pm 0.09$ & $24.98 \pm 9.78$ \\
Organic content & $\%$ & $31.05 \pm 8.35$ & $16.12 \pm 5.04$ & $6.93 \pm 4.85$ \\
\hline & $\%$ & $2.04 \pm 0.39$ & $6.40 \pm 3.65$ & $33.42 \pm 14.60$ \\
& $500 \mu \mathrm{m}$ & $22.80 \pm 16.07$ & $10.19 \pm 7.91$ & $14.89 \pm 10.50$ \\
Particle size & $250 \mu \mathrm{m}$ & $13.84 \pm 5.58$ & $16.15 \pm 6.28$ & $16.37 \pm 10.30$ \\
& $125 \mu \mathrm{m}$ & $17.48 \pm 10.67$ & $11.90 \pm 7.60$ & $3.32 \pm 1.28$ \\
& $90 \mu \mathrm{m}$ & $4.58 \pm 2.63$ & $1.34 \pm 1.25$ & $2.36 \pm 1.37$ \\
\hline
\end{tabular}

Table 4. DGT and total metal analysis results applied to water samples (September 2017-April 2018) (mean $\pm \mathrm{SD}, \mathrm{mg} / \mathrm{L})$

\begin{tabular}{c|lcccccc}
\hline \multirow{3}{*}{ SWQR } & $\mathrm{mg} / \mathrm{L}$ & $\mathrm{Pb}$ & $\mathrm{Ni}$ & $\mathrm{Fe}$ & $\mathrm{Zn}$ & $\mathrm{Cu}$ & $\mathrm{Al}$ \\
\cline { 2 - 8 } & $\mathrm{min}$ & 0.0012 & 0.004 & 0.036 & 0.0059 & 0.0016 & 2.2 \\
& $\mathrm{~m}$ ax & $>0.014$ & $>0.034$ & $>0.101$ & $>0.231$ & $>0.0031$ & $>27$ \\
\hline & $\mathrm{S} 1$ & $0.025 \pm 0.0028$ & $0.005 \pm 0.0007$ & $1.839 \pm 0.0133$ & $0.190 \pm 0.0023$ & $0.001 \pm 0.0001$ & $0.001 \pm 0.0001$ \\
$\mathrm{D} 2017$ & $\mathrm{~S} 2$ & $0.024 \pm 0.0044$ & $0.005 \pm 0.0001$ & $0.408 \pm 0.0013$ & $0.134 \pm 0.0020$ & $0.000 \pm 0.0013$ & $0.001 \pm 0.0001$ \\
& $\mathrm{~S} 3$ & $0.022 \pm 0.0013$ & $0.013 \pm 0.0007$ & $0.487 \pm 0.0049$ & $0.220 \pm 0.0017$ & $0.008 \pm 0.0002$ & $0.291 \pm 0.0029$ \\
& $\mathrm{~S} 5$ & $0.028 \pm 0.0020$ & $0.010 \pm 0.0005$ & $1.799 \pm 0.0117$ & $0.209 \pm 0.0010$ & $0.013 \pm 0.0001$ & $2.442 \pm 0.3518$ \\
\hline & $\mathrm{S} 1$ & $0.002 \pm 0.0035$ & $0.003 \pm 0.0011$ & $0.650 \pm 0.0006$ & $0.055 \pm 0.0004$ & $0.017 \pm 0.0002$ & $0.08 \pm 0.0005$ \\
W 2017 & $\mathrm{S} 2$ & $0.003 \pm 0.0009$ & $0.002 \pm 0.0003$ & $0.391 \pm 0.0024$ & $0.044 \pm 0.0006$ & $0.004 \pm 0.0001$ & $0.101 \pm 0.0010$ \\
& $\mathrm{~S} 3$ & $\mathrm{BDL} \pm 0.0008$ & $0.003 \pm 0.0014$ & $0.518 \pm 0.0028$ & $0.069 \pm 0.0004$ & $0.008 \pm 0.0002$ & $0.208 \pm 0.0024$ \\
& $\mathrm{~S} 5$ & $0.003 \pm 0.0032$ & $0.008 \pm 0.0003$ & $1.404 \pm 0.0105$ & $0.058 \pm 0.0008$ & $0.0039 \pm 0.0004$ & $1.197 \pm 0.0018$ \\
\hline & $\mathrm{S} 1$ & $0.016 \pm 0.0029$ & $0.005 \pm 0.0004$ & $0.198 \pm 0.0012$ & $0.112 \pm 0.0152$ & $0.001 \pm 0.0002$ & $0.001 \pm 0.0001$ \\
D 2018 & $\mathrm{S} 2$ & $0.027 \pm 0.0027$ & $0.006 \pm 0.0003$ & $0.113 \pm 0.0006$ & $0.208 \pm 0.0014$ & $0.024 \pm 0.0003$ & $0.035 \pm 0.0428$ \\
& $\mathrm{~S} 3$ & $0.024 \pm 0.0026$ & $0.061 \pm 0.0007$ & $0.229 \pm 0.0004$ & $0.148 \pm 0.0027$ & $0.001 \pm 0.0001$ & $0.000 \pm 0.0001$ \\
& $\mathrm{~S} 5$ & $0.020 \pm 0.0020$ & $0.001 \pm 0.0007$ & $0.396 \pm 0.0011$ & $0.152 \pm 0.0005$ & $0.013 \pm 0.0001$ & $0.118 \pm 0.1814$ \\
\hline & $\mathrm{S} 1$ & $0.003 \pm 0.0045$ & $0.001 \pm 0.0004$ & $1.418 \pm 0.0215$ & $0.055 \pm 0.0010$ & $0.004 \pm 0.0003$ & $0.97 \pm 0.0177$ \\
W 2018 & $\mathrm{S} 2$ & $\mathrm{BDL} \pm 0.0009$ & $\mathrm{BDL} \pm 0.0004$ & $0.226 \pm 0.0010$ & $0.077 \pm 0.0008$ & $0.0037 \pm 0.0004$ & $0.063 \pm 0.0010$ \\
& $\mathrm{~S} 3$ & $0.005 \pm 0.0004$ & $0.025 \pm 0.0001$ & $0.190 \pm 0.0011$ & $0.181 \pm 0.0025$ & $0.005 \pm 0.0005$ & $0.02 \pm 0.0008$ \\
& $\mathrm{~S} 5$ & $0.002 \pm 0.0035$ & $\mathrm{BDL} \pm 0.0004$ & $1.247 \pm 0.0109$ & $0.099 \pm 0.0010$ & $0.0045 \pm 0.0001$ & $0.3 \pm 0.0014$ \\
\hline
\end{tabular}

SWQR: Surface Water Quality Regulation, D 2017: This study September 2017 DGT, W 2017: This study September 2017 Water, D 2018: This study April 2018 DGT, W 2018: This study April 2018 Water 
Total $\mathrm{Pb}$ can be found between 0.0012 and $0.014 \mathrm{mg} / \mathrm{L}$ in ground and surface waters. Generally, industrial enterprises join the water body. Water with a lead $(\mathrm{Pb})$ concentration of $0.01 \mathrm{mg} / \mathrm{L}$ and above is considered contaminated. It has also been reported that lead affects the osmotic balance and ionization in aquatic organisms and causes histopathological changes in the liver (Atay and Pulatsu, 2000; Mutlu et al., 2016; Mutlu and Aydın Uncumusaoglu, 2017) When the analysis results given in Table 4 are examined, the maximum value has been exceeded at all sampling points. Looking at water samples, $\mathrm{Pb}$ is below the limit value at all sampling points. Similarly, conducted by Mutlu et al. (2016) in the Serefiye Dam located above Kizilırmak, $\mathrm{Pb}$ was found to be below the limit value with $0.003 \mathrm{mg} / \mathrm{L}$. Total $\mathrm{Ni}$ is found in very low concentrations in surface waters. $\mathrm{Ni}$, which is desired to be between 0.004 and $0.034 \mathrm{mg} / \mathrm{L}$ in surface waters, was detected below the limit value at all sampling points except $\mathrm{S} 3$ sampling point and $\mathrm{Ni}$ is also below the limit value in water samples like $\mathrm{Pb}$. In the study conducted by Mutlu et al (2016), Ni and $\mathrm{Zn}$ remained within the limit values with $0.022 \mathrm{mg} / \mathrm{L}$ and $0.061 \mathrm{mg} / \mathrm{L}$.

Total Fe can be found in water sources as various compounds and is desired to be between 0.036 and 0.101 $\mathrm{mg} / \mathrm{L}$ limit value. It has been observed that the measurement results are above the maximum value at all sampling points. Likewise, Fe concentrations measured in water are also seen above the limit value. $\mathrm{Zn}$ mixed into the water with industrial and toxic wastes can cause serious problems in terms of environment and human health if it is present in high amounts. When the measurement results are examined, it is seen that the limit value of $0.231 \mathrm{mg} / \mathrm{L}$ is not exceeded.

Total $\mathrm{Cu}$ is usually found in low concentrations in natural waters if there is no contact with metal-containing areas. It can interfere with water resources due to rock erosion and industrial origin (Oğuz, 2015). It is seen that the limit value of $0.0031 \mathrm{mg} / \mathrm{L}$ for $\mathrm{Cu}$ is not exceeded in surface waters. In water measurements, the $\mathrm{Cu}$ concentration is above the limit value at all sampling points. Al can be found above a certain level in the natural structure of water. Although the total amount of $\mathrm{Al}$ is dependent on many physical and mineralogical factors, especially acid rain can increase the Al level (Yavuz et al., 2013). It is seen that the element $\mathrm{Al}$, which is desired to be between 2.2 and $27 \mathrm{mg} / \mathrm{L}$ according to SWQR, does not exceed the limit value in both water and DGT analyses.

DGT metal analysis results applied to sediment samples were evaluated according to the International Sediment Quality Guidelines (SQG). According to the effect level of sediment quality criteria; LEL (Lowest Effect Level); Below this limit, no adverse effects are generally observed on living organisms. TEL (Threshold Effect Level); Adverse effects on living organisms rarely occur below this limit. MET (Minimum Effect treshold); It is expressed as TET (Toxic Effect Threshold) (NOAA, 1999).

In Table 5, the comparison of DGT heavy metal results in sediment samples according to SQG is included. When the DGT metal analysis results applied to December 2017 sediment samples are examined, it is seen that the metal concentrations increase with depth according to the different depths of four different sampling points.
Since the measurement values of $\mathrm{Cu}, \mathrm{Cr}$ and $\mathrm{Cd}$ elements are below the measurement limit, they are not included in the table and are not evaluated. According to the analysis results, all measurements except $\mathrm{S} 1(2 \mathrm{~cm})$ and $\mathrm{S} 3(0.5 \mathrm{~cm})$ are greater than the limit value of TEL $(35 \mu \mathrm{g} /$ g) for $\mathrm{Pb}$. It was observed that the LEL $(31 \mu \mathrm{g} / \mathrm{g})$ limit value was exceeded in all measurements except $\mathrm{S} 1(2 \mathrm{~cm})$. At the same time, the limit value of MET $(42 \mu \mathrm{g} / \mathrm{g})$ is at all depths except S1 $(2 \mathrm{~cm}), \mathrm{S} 2(0.5 \mathrm{~cm}), \mathrm{S} 3(0.5 \mathrm{~cm}), \mathrm{S} 3$ $(2 \mathrm{~cm}), \mathrm{S} 5(0.5 \mathrm{~cm}), \mathrm{S} 5(3 \mathrm{~cm})$. It appears to be greater than the value. The TET value, which has a limit value of 170 $\mu \mathrm{g} / \mathrm{g}$, has not been exceeded at any sampling point and depth, so the toxic effect is at an acceptable level. Pb used in industrial activities in the region cannot be removed due to its biological effect and tends to accumulate in the sediment (Eqani et al., 2016). When the total metal concentrations measured in the sediment are analyzed in December, it is seen that the SQG values are not exceeded at all sampling points.

$\mathrm{Ni}$ is between the limit values of TEL $(18 \mu \mathrm{g} / \mathrm{g})$ and LEL $(16 \mu \mathrm{g} / \mathrm{g})$. Larger results were obtained at the depths of S2 $(4 \mathrm{~cm}), S 2(10 \mathrm{~cm}), \mathrm{S} 2(12 \mathrm{~cm})$ and it is seen that the critical limit is exceeded. The limit value of MET (35 $\mu \mathrm{g} /$ $\mathrm{g})$ is higher than this value at S2 $(10 \mathrm{~cm})$ and $\mathrm{S} 2(12 \mathrm{~cm})$ depths. It is seen that the limit value of TET $(61 \mu \mathrm{g} / \mathrm{g})$ is not exceeded at any sampling point and depth.

$\mathrm{Fe}$ is one of the most abundant elements in the earth's crust. For Fe, the LEL $(20000 \mu \mathrm{g} / \mathrm{g})$ limit value is not exceeded for measurements except for $\mathrm{S} 2(4 \mathrm{~cm}), \mathrm{S} 2$ $(10 \mathrm{~cm}), \mathrm{S} 2(12 \mathrm{~cm}), \mathrm{S} 3(2 \mathrm{~cm}), \mathrm{S} 3(4 \mathrm{~cm}), \mathrm{S} 3(8 \mathrm{~cm})$ and $\mathrm{S} 5$ $(7 \mathrm{~cm})$. Due to the natural presence of sediment in its structure, there are no TEL, MET and TET limit values for Fe specified in the standards.

Limit values for the $\mathrm{Zn}$ element are TEL $(123 \mu \mathrm{g} / \mathrm{g})$ and LEL $(120 \mu \mathrm{g} / \mathrm{g})$. It has been determined that these values are exceeded at all depths of each sampling point. The MET $(150 \mu \mathrm{g} / \mathrm{g}$ ) limit value is higher than the critical value across the depth at all sampling points, except S3 $(0.5 \mathrm{~cm})$. It is seen that the TET $(540 \mu \mathrm{g} / \mathrm{g})$ limit value is exceeded at $\mathrm{S} 5(3 \mathrm{~cm})$ and $\mathrm{S} 1(4 \mathrm{~cm})$ depth. Similarly, in the study by Zhang et al. (2019), it was found that $\mathrm{Zn}, \mathrm{Ni}$ and $\mathrm{Pb}$ metals exceed the TEL value.

When the DGT metal analysis results applied to the September 2017 and April 2018 sediment samples are examined, it is seen that the metal concentrations at different depths of the S5 sampling point increased throughout the depth at both times. In September 2017 samples, TEL $(35 \mu \mathrm{g} / \mathrm{g})$ for $\mathrm{Pb}$ is greater than this value at depths S5 (4cm) and S5 (12cm), and LEL $(31 \mu \mathrm{g} / \mathrm{g})$ at all depths except S5 $(8 \mathrm{~cm})$. In all of the April 2018 samples, higher results were obtained for $\mathrm{Pb}$ than the limit values of TEL $(35 \mu \mathrm{g} / \mathrm{g})$ and LEL $(31 \mu \mathrm{g} / \mathrm{g})$. The MET (42 $\mu \mathrm{g} / \mathrm{g}$ ) limit value exceeded the critical value at depths of S5 $(4 \mathrm{~cm})$ in September 2017 and S5 $(0.5 \mathrm{~cm})$ in April 2018. Measurement results are lower than the TET $(170 \mu \mathrm{g}$ / g) limit value in both seasons.

According to the total metal results measured in the sediment, only $\mathrm{Zn}$ and Ni metal in all seasons and sampling points are above some limit values at S3 sampling point. Over the MET $(150 \mu \mathrm{g} / \mathrm{g})$ limit value for $\mathrm{Zn}$; For Ni, December 2017 values were found above the TEL $(18 \mu \mathrm{g} /$ $\mathrm{g})$, LEL $(16 \mu \mathrm{g} / \mathrm{g})$, MET $(35 \mu \mathrm{g} / \mathrm{g})$ limit values, and above the TET $(61 \mu \mathrm{g} / \mathrm{g})$ value in September 2017 and April 2018. 
Table 5. DGT and total metal analysis results applied to sediment samples (mean $\pm \mathrm{SD}, \mu \mathrm{g} / \mathrm{g}$ )

\begin{tabular}{|c|c|c|c|c|c|}
\hline & $(\mu \mathrm{g} / \mathrm{g})$ & $\mathrm{Fe}$ & $\mathrm{Zn}$ & $\mathrm{Ni}$ & $\mathrm{Pb}$ \\
\hline \multirow{4}{*}{ SQG } & ${ }^{\text {aTEL }}$ & - & 123.00 & 18.00 & 35.00 \\
\hline & ${ }^{\mathrm{a}} \mathrm{LEL}$ & 20000 & 120.00 & 16.00 & 31.00 \\
\hline & ${ }^{\mathrm{a}} \mathrm{MET}$ & - & 150.00 & 35.00 & 42.00 \\
\hline & 'TET & - & 540.00 & 61.00 & 170.00 \\
\hline \multirow{16}{*}{$\begin{array}{l}\text { December } 2017 \\
\text { DGT }\end{array}$} & $\mathrm{S} 1(0.5 \mathrm{~cm})$ & $1194.00 \pm 0.24$ & $222.00 \pm 0.28$ & $0.00 \pm 0.32$ & $48.00 \pm 1.00$ \\
\hline & $\mathrm{S} 1(2 \mathrm{~cm})$ & $6308.00 \pm 4.04$ & $224.00 \pm 0.56$ & $8.00 \pm 0.12$ & $28.00 \pm 2.64$ \\
\hline & $\mathrm{S} 1(4 \mathrm{~cm})$ & $10627.20 \pm 0.32$ & $652.80 \pm 0.32$ & $14.40 \pm 0.12$ & $52.80 \pm 2.76$ \\
\hline & $\mathrm{S} 1(8 \mathrm{~cm})$ & $19334.00 \pm 7.64$ & $456.00 \pm 0.36$ & $12.00 \pm 0.16$ & $84.00 \pm 3.16$ \\
\hline & $\mathrm{S} 2(0.5 \mathrm{~cm})$ & $3856.00 \pm 0.16$ & $324.00 \pm 1.80$ & $4.00 \pm 0.08$ & $40.00 \pm 0.84$ \\
\hline & $\mathrm{S} 2(2 \mathrm{~cm})$ & $14416.00 \pm 18.20$ & $240.00 \pm 3.96$ & $12.00 \pm 0.12$ & $52.00 \pm 0.60$ \\
\hline & $\mathrm{S} 2(4 \mathrm{~cm})$ & $37968.00 \pm 0.80$ & $380.00 \pm 0.76$ & $28.00 \pm 0.12$ & $56.00 \pm 0.92$ \\
\hline & $\mathrm{S} 2(10 \mathrm{~cm})$ & $62920.00 \pm 0.20$ & $452.00 \pm 0.56$ & $52.00 \pm 0.20$ & $52.00 \pm 1.36$ \\
\hline & $\mathrm{S} 2(12 \mathrm{~cm})$ & $62800.00 \pm 38.76$ & $408.00 \pm 0.40$ & $48.00 \pm 0.12$ & $84.00 \pm 0.80$ \\
\hline & $\mathrm{S} 3(0.5 \mathrm{~cm})$ & $5908.00 \pm 12.00$ & $132.00 \pm 0.16$ & $8.00 \pm 0.08$ & $32.00 \pm 0.04$ \\
\hline & $\mathrm{S} 3(2 \mathrm{~cm})$ & $32660.00 \pm 81.20$ & $524.00 \pm 0.48$ & $8.00 \pm 0.12$ & $40.00 \pm 2.44$ \\
\hline & $\mathrm{S} 3(4 \mathrm{~cm})$ & $52000.00 \pm 90.00$ & $444.00 \pm 0.48$ & $8.00 \pm 0.20$ & $48.00 \pm 3.04$ \\
\hline & $\mathrm{S} 3(8 \mathrm{~cm})$ & $69720.00 \pm 7.76$ & $396.00 \pm 0.60$ & $12.00 \pm 0.08$ & $44.00 \pm 0.60$ \\
\hline & $\mathrm{S} 5(0.5 \mathrm{~cm})$ & $2696.00 \pm 34.84$ & $152.00 \pm 0.40$ & $16.00 \pm 0.08$ & $40.00 \pm 0.04$ \\
\hline & $\mathrm{S} 5(3 \mathrm{~cm})$ & $10448.00 \pm 63.20$ & $4536.00 \pm 0.60$ & $16.00 \pm 0.20$ & $40.00 \pm 0.08$ \\
\hline & $\mathrm{S} 5(7 \mathrm{~cm})$ & $40280.00 \pm 128.00$ & $316.00 \pm 0.44$ & $8.00 \pm 0.24$ & $48.00 \pm 0.04$ \\
\hline \multirow{4}{*}{$\begin{array}{l}\text { December } 2017 \\
\text { Sediment }\end{array}$} & $\mathrm{S} 1$ & $12124.37 \pm 461.21$ & $62.77 \pm 5.61$ & $9.96 \pm 1.46$ & $7.43 \pm 0.66$ \\
\hline & $\mathrm{S} 2$ & $11656.98 \pm 387.18$ & $32.69 \pm 3.57$ & $9.34 \pm 2.02$ & $5.37 \pm 0.38$ \\
\hline & S3 & $9659.96 \pm 301.88$ & $300.60 \pm 17.91$ & $60.30 \pm 6.32$ & $5.34 \pm 0.61$ \\
\hline & S5 & $13147.54 \pm 458.66$ & $30.88 \pm 4.82$ & $14.00 \pm 1.76$ & $0.09 \pm 0.29$ \\
\hline \multirow{5}{*}{$\begin{array}{l}\text { September } \\
2017 \\
\text { DGT }\end{array}$} & $\mathrm{S} 5(0.5 \mathrm{~cm})$ & $6976.00 \pm 0.20$ & $244.00 \pm 0.24$ & $8.00 \pm 0.24$ & $32.00 \pm 0.92$ \\
\hline & $\mathrm{S} 5(3 \mathrm{~cm})$ & $8356.00 \pm 0.16$ & $256.00 \pm 0.52$ & $12.00 \pm 0.04$ & $32.00 \pm 1.52$ \\
\hline & $\mathrm{S} 5(4 \mathrm{~cm})$ & $24344.00 \pm 0.32$ & $376.00 \pm 0.16$ & $4.00 \pm 0.04$ & $44.00 \pm 0.48$ \\
\hline & $\mathrm{S} 5(8 \mathrm{~cm})$ & $17204.00 \pm 1.20$ & $380.00 \pm 0.28$ & $12.00 \pm 0.04$ & $28.00 \pm 3.04$ \\
\hline & $\mathrm{S} 5(12 \mathrm{~cm})$ & $6076.00 \pm 2.40$ & $408.00 \pm 0.20$ & $12.00 \pm 0.08$ & $36.00 \pm 1.00$ \\
\hline \multirow{4}{*}{$\begin{array}{l}\text { September } \\
2017 \\
\text { Sediment }\end{array}$} & S1 & $14082.44 \pm 453.51$ & $26.51 \pm 9.62$ & $11.46 \pm 3.84$ & $3.07 \pm 0.58$ \\
\hline & S2 & $11913.22 \pm 347.42$ & $64.38 \pm 9.39$ & $9.93 \pm 4.43$ & $5.59 \pm 0.94$ \\
\hline & S3 & $11275.36 \pm 280.61$ & $390.13 \pm 17.09$ & $92.79 \pm 6.48$ & $5.10 \pm 0.53$ \\
\hline & S5 & $15884.94 \pm 464.84$ & $64.08 \pm 5.60$ & $11.76 \pm 3.21$ & $7.24 \pm 1.31$ \\
\hline \multirow{3}{*}{$\begin{array}{l}\text { April } 2018 \\
\text { DGT }\end{array}$} & $\mathrm{S} 5(0.5 \mathrm{~cm})$ & $256.00 \pm 43.84$ & $392.00 \pm 0.16$ & $16.00 \pm 0.16$ & $44.00 \pm 1.12$ \\
\hline & $\mathrm{S} 5(1.5 \mathrm{~cm})$ & $396.00 \pm 29.44$ & $216.00 \pm 0.48$ & $12.00 \pm 0.20$ & $36.00 \pm 2.20$ \\
\hline & $\mathrm{S} 5(6.5 \mathrm{~cm})$ & $492.00 \pm 5.40$ & $316.00 \pm 0.52$ & $16.00 \pm 0.16$ & $40.00 \pm 1.88$ \\
\hline \multirow{4}{*}{$\begin{array}{l}\text { April } 2018 \\
\text { Sediment }\end{array}$} & S1 & $12917.21 \pm 317.58$ & $24.26 \pm 4.81$ & $7.31 \pm 1.51$ & $4.84 \pm 0.84$ \\
\hline & $\mathrm{S} 2$ & $15863.10 \pm 507.39$ & $40.74 \pm 4.71$ & $7.44 \pm 1.93$ & $0.96 \pm 0.36$ \\
\hline & S3 & $10951.63 \pm 317.45$ & $449.99 \pm 14.97$ & $135.45 \pm 7.02$ & $14.49 \pm 0.83$ \\
\hline & S5 & $15689.93 \pm 31.61$ & $21.67 \pm 3.66$ & $6.97 \pm 1.07$ & $7.05 \pm 0.81$ \\
\hline
\end{tabular}

a: NOAA., 1999.

Table 6. Correlation matrix showing $r$ values between Csed, Csed-DGT, Csu and Csu-DGT for metals. (*) indicates an significant relationship $(\mathrm{P}<0.001)$

\begin{tabular}{|c|c|c|c|c|c|}
\hline & & Csed & Csed-DGT & $\overline{\mathrm{Csu}}$ & Csu-DGT \\
\hline \multirow[t]{4}{*}{$\mathrm{Fe}$} & Csed & 1 & $0.954 *$ & 0.631 & 0.525 \\
\hline & Csed-DGT & & 1 & 0.564 & 0.494 \\
\hline & $\mathrm{Csu}$ & & & 1 & $0.985^{*}$ \\
\hline & Csu-DGT & & & & 1 \\
\hline \multirow[t]{4}{*}{$\mathrm{Ni}$} & Csed & 1 & $0.971 *$ & $0.804^{*}$ & $0.969 *$ \\
\hline & Csed-DGT & & 1 & $0.856^{*}$ & $0.989 *$ \\
\hline & Csu & & & 1 & $0.853 *$ \\
\hline & Csu-DGT & & & & 1 \\
\hline \multirow[t]{4}{*}{$\mathrm{Zn}$} & Csed & 1 & $0.969 *$ & -0.566 & 0.071 \\
\hline & Csed-DGT & & 1 & -0.347 & 0.315 \\
\hline & Csu & & & 1 & $0.779 *$ \\
\hline & Csu-DGT & & & & 1 \\
\hline \multirow[t]{4}{*}{$\mathrm{Pb}$} & Csed & 1 & $0.729 *$ & 0.922 & $0.776^{*}$ \\
\hline & Csed-DGT & & 1 & 0.623 & 0.215 \\
\hline & $\mathrm{Csu}$ & & & 1 & $0.892 *$ \\
\hline & Csu-DGT & & & & 1 \\
\hline
\end{tabular}



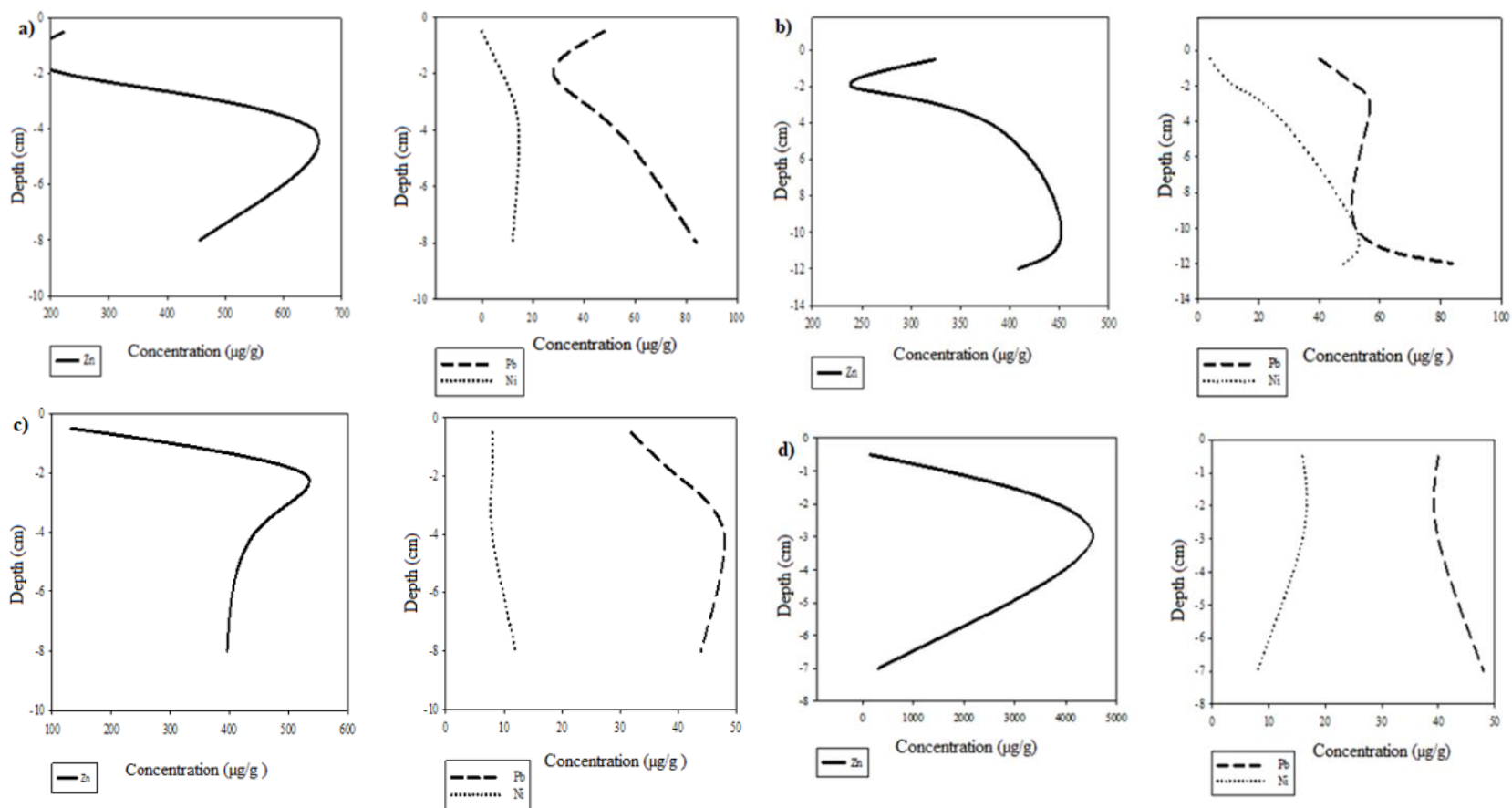

Figure 5. Variation of sediment metal concentrations across depth a) S1 b) S2 c) S3 d) S5 (December 2017)

When all analysis results are evaluated, six heavy metal concentrations measured in water samples are listed as large to small as $\mathrm{Al}>\mathrm{Fe}>\mathrm{Zn}>\mathrm{Cu}>\mathrm{Ni}>\mathrm{Pb}$, and in DGT applied to water as $\mathrm{Al}>\mathrm{Fe}>\mathrm{Zn}>\mathrm{Pb}>\mathrm{Ni}>\mathrm{Cu}$. There are differences between $\mathrm{Cu}$ and $\mathrm{Pb}$ metal in DGT concentrations according to metal concentrations in water. Similarly, in the study conducted by Zhang et al., 2019, $\mathrm{Zn}>\mathrm{Pb}$ between sediment and DGT and $\mathrm{Ni}>\mathrm{Cu}$ between sediment and sediment pore water. Based on the results here, it is thought that $\mathrm{Zn}, \mathrm{Ni}$ and $\mathrm{Pb}$ oscillation is better than $\mathrm{Cu}$ metal. According to the comparison of the metal results in the sediment according to the DGT results, while the Csed results were ranked as $\mathrm{Fe}>$ $\mathrm{Zn}>\mathrm{Ni}>\mathrm{Pb}$, Csed-DGT is also listed as $\mathrm{Fe}>\mathrm{Zn}>\mathrm{Pb}>\mathrm{Ni}$. During exposure to DGT, the sampler surface may become contaminated due to possible biofilm growth. This contamination is suspected to induce a bias to quantification by altering the accumulation of metal through interaction with them (Uher et al., 2012; Uher et al., 2017). Devillers et al. (2017) stated that the accumulation of metal cations, especially $\mathrm{Pb}$, is restricted due to the sorption event. It is noted that fouling limits the amount of cation deposited by the binding phase and, in the worst cases, can result in an underestimation of 40 to $90 \%$ of DGT.

Figure 5 shows the variation with depth of DGT heavy metal results for the period of December 2017. a) Depth concentration change of S1 sample, b) Depth concentration change of S2 sample, c) Depth concentration change of S3 sample and d) Depth of S5 sample shows the concentration change in December 2017. When sediment metal concentrations are examined, Fe metal concentrations increase throughout the depth. According to Figure 5, it has been determined that there are only visible changes in $\mathrm{Zn}$ metal, the concentrations of $\mathrm{Pb}$ and $\mathrm{Ni}$ metals are very low and change with depth is less. The increase along the depth indicates the accumulation of pollution in the sediment layer based on the past, while the unchanged concentration values indicate that the accumulation of pollution at the same level is continuous.

\section{Evaluation of Statistical Analysis Results}

Relationships between Csed, Csed-DGT, Csu and CsuDGT are shown as a correlation matrix for $\mathrm{Fe}, \mathrm{Ni}, \mathrm{Zn}$ and $\mathrm{Pb}$ metals in Table 6. Generally, significant correlations were observed between the two measurements; these are Csed, Csed-DGT $\left(\mathrm{r}^{2}=0.53-0.94\right)$, Csu and Csu-DGT $\left(\mathrm{r}^{2}=\right.$ 0.60-0.97). Significant correlations were observed between Csed, Csed-DGT, Csu-DGT for three metals $(\mathrm{Fe}, \mathrm{Ni}, \mathrm{Pb})$ other than Zn. In the study conducted by Cindric et al. (2020), they thought that the low correlation in $\mathrm{Zn}$ correlations compared to other metals was due to contamination (Cindrić et al., 2020). While high positive correlations are observed between Csed, Csed-DGT and Csu and Csu-DGT, negative correlations between CsedCsu or Csed-Csu-DGT are thought to be due to the different dynamics of water and sediment in terms of heavy metal release. The results generally stated that similar to the study conducted by Zhang et al. (2020), Pb is hard to release from the sediment, while $\mathrm{Cu}, \mathrm{Ni}$ and $\mathrm{Zn}$ are released more than $\mathrm{Pb}$. Amato et al. (2016) reported that there are strong relationships between time dependent DGT fluxes in $\mathrm{Pb}$ and $\mathrm{Zn}$ bioaccumulation.

\section{Conclusions}

Determining the properties of sediment and the level of contamination with metals is very important to understand and determine its impact on the aquatic environment. When determining the water and sediment quality, it is important to use an undisturbed sediment/water interface to decide on remediation methods. Within the scope of this study, it was aimed to determine the effectiveness of the traditional active (manual) sampling method and the DGT method, which has recently been used in our country, in the assessment of water and sediment pollution.

When the obtained analysis results are examined, it is seen that the presence of metal in water samples does not exceed the limit values, but the presence of heavy metals 
such as $\mathrm{Zn}, \mathrm{Ni}, \mathrm{Pb}$ in sediment samples has been detected. It has been observed that the accumulation of $\mathrm{Zn}$ in the sediment increases throughout the depth, the change of $\mathrm{Ni}$ and $\mathrm{Pb}$ with depth is not much and there is a continuous accumulation at the same rate.

In order to evaluate the reliability of the DGT method, it is recommended to perform other studies with this method on site and in the laboratory environment. At the same time, more emphasis is needed on sediment quality and chemical monitoring.

Considering in general;

- Ex-situ analyses cannot reflect real information on metal species; However, if working with DGT, it can be detected in unstable and soluble metal types.

- In the (grab) manual sampling method, complete preservation of samples is almost impossible due to the ongoing chemical and biological changes that occur during sample collection, transport, storage and processing (Menegário et al., 2017); This contamination can be minimized by using the DGT method (Gao et al., 2020).

- Manuel sampling is not sensitive enough to detect metal speciation in natural environments, especially for samples with low metal concentrations. As in the study results, the DGT method was more sensitive and approximately 2-10 times more sensitive than the standard methods.

In addition to these;

- DGT method effectively measures total dissolved metal concentrations throughout the depth,

- Variable metal concentrations can be measured repeatedly and integrated over time,

- Considering the principles of the Water Framework Directive, it has been observed that the DGT method is an effective tool in water and sediment pollution monitoring.

- Combining the advantages of mixed monitoring strategies that use passive and manual sampling methods in parallel or alternatively depending on the areas studied, increasing feedback on larger DGT deployments, continuing to apply the use of DGT for water and sediment quality monitoring as much as possible, and bringing their advantages to sea or river. It should be increased by application to other media such as mouth water.

\section{Acknowledgements}

This study was supported by the scientific research project of Ondokuz Mayıs University PYO.MUH.1904.18.005.

\section{References}

Akbal F, Gürel L, Bahadır T, Güler B, Bakan G, Büyükgüngör H. 2011. Multivariate Statistical Techniques for the Assessment of Surface Water Quality at the Mid-Black Sea Coast of Turkey. Water Air Soil Pollution, 216: 21- 37. doi.org/10.1007/s11270-010-0511-0.

Alkan N, Alkan A, Akbas U, Fisher A. 2015. Metal Pollution Assessment in Sediments of The Southeastern Black Sea Coast of Turkey. Soil Sediment Contamination: An International Journal, 24:3, 290-305.
Allan IJ, Knutsson J, Guigues N, Mills GA, Fouillac AM, Greenwood R. 2008. Chemcatcher ${ }^{\circledR}$ and DGT Passive Sampling Devices for Regulatory Monitoring of Trace Metals in Surface Water. Journal Environmental Monitoring, 10:821-829. doi.org/ 10.1039/B802581A.

Alpsarı Pond (Korgun-Çankırı). Turkish Journal of Fisheries and Aquatic Sciences, 17, 1231-1243

Amato ED, Simpson SL, Remaili TM, Spadaro DA, Jarolimek CV, Jolley DF. 2016. Assessing the Effects of Bioturbation on Metal Bioavailability in Contaminated Sediments by Diffusive Gradients in Thin Films (DGT). Environmental Science Technology, 50: 3055-3064.

Atıcı T. 2004. Sarıyar Baraj1 Planktonik Algleri Kısım: I Cyanophyta. Süleyman Demirel Üniversitesi Eğirdir $\mathrm{Su}$ Ürünleri Fakültesi Dergisi, 2 (12): 94.

Aydın H, Ustaoğlu F, Tepe Y, Soylu EN. 2021 Assessment of Water Quality of Streams in Northeast Turkey by Water Quality Index and Multiple Statistical Methods. Environmental Forensics, https://doi.org/10.1080/15275922. 2020.1836074.

Bakan G, Büyükgüngör H. 2000. The Black Sea. Marine Pollution Bulletin, Vol. 41: No. 1-6, 24-43.

Bakan G. 1995. The Study of the Sapanca Lake Ecosystem; Sediment Characterization and Water Quality Modelling, Ph. D. Degree. Institute of Natural and Applied Sciences, METU, Ankara, Turkey.

Bakan G. 2000. Çevre Sedimantolojisi ve Sediman Kalite Kriter Çalışmaları. Çevre Bilim ve Teknoloji, 1:1, 14-23.

Bat L, Sezgin M, Gökkurt BO, Üstün F, Şahin F. 2013. Determination of Heavy Metals in Some Commercial Fish from the Black Sea Coast of Turkey. Walailak Journal Science Technology, 10:6, 581-9.

Belzile N, Chen YW, Gunn JM, Dixit SS. 2004. Sediment Trace Metal Profiles in Lakes of Killarney Park, Canada: From Regional to Continental İnfluence. Environmental Pollution, 130: 239-48. doi.org/10.1016/j.envpol.2003.12.003.

Budasheva H, Kravos A, Korte D, Bratkič A, Gao Y, Franko M. 2019. Determination of Dissolved İron Redox Species in Freshwater Sediment Using DGT Technique Coupled to BDS. Acta Chimica Slovenica, 66(1), 239-246. doi:https://doi.org/10.17344/acsi.2018.4848.

Campana O, Blasco J, Simpson SL. 2013. Demonstrating the Appropriateness of Developing Sediment Quality Guidelines Based on Sediment Geochemical Properties. Environmental Science and Technology, 47: 7483-7489.

Canpolat Ö, Varol M, Okan Ö, Eriş K, Çağlar M. 2020. A Comparison of Trace Element Concentrations in Surface and Deep Water of the Keban Dam Lake (Turkey) and associated Health Risk Assessment. Environmental Research, 190:110012.

Chaudhary M, Quanz M, Williams J, Maltby EA, Oakes K, Spooner I, Walker T. 2020. Assessment of Metal(loid) Concentrations Using Diffusive Gradient Thin (DGT) Films in Marine, Freshwater and Wetland Aquatic Ecosystems Impacted by Industrial Effluents. Case Studies in Chemical and Environmental Engineering, 2:1-8 https://doi.org/ 10.1016/j.cscee.2020.100041.

Cindrić AM, Marcinek S, Garnier C, Salaün P, Cukrov N, Oursel B, Lenoble V, Omanović D. 2020. Evaluation of Diffusive Gradients in Thin Films (DGT) Technique for Speciation of Trace Metals in Estuarine Waters - A Multimethodological Approach. Science Total Environment, 15:721:137784. doi: 10.1016/j.scitotenv.2020.137784. Epub 2020 Mar 6. PMID: 32172124

Costello DM, Hammerschmidt CR, Burton G.A. 2015. Copper Sediment Toxicity and Partitioning During Oxidation in a Flow-Through Flume. Environmental Science and Technology, 49:6926-6933. 
Davison W, Fones G, Harper M, Teasdale P, Zhang H. 2000. Dialysis, DET and DGT: In Situ Diffusional Techniques for Studying Water, Sediments and Soils, In: In Situ Chemical Analysis in Aquatic Systems, J. Buffle and G. Horvai, Eds.:Wiley, pp 495-569.

Davison W, Zhang H. 1994. In Situ Speciation Measurements of Trace Components in Natural Waters Using Thin-Film Gels. Nature 367, 546-548. doi.org/10.1038/ 367546a0.

De Jonge M, Teuchies J, Meire P, Blust R, Bervoets L. 2012a. The İmpact of Increased Oxygen Conditions on MetalContaminated Sediments Part II: Effects on Metal Accumulation and Toxicity in Aquatic İnvertebrates. Water Research, doi.org/10.1016/j.watres.2012.03.035.

De Jonge M, Teuchies J, Meire P, Blust R, Bervoets L. 2012 b. The Impact of Increased Oxygen Conditions on MetalContaminated Sediments Part I: Effects on Redox Status, Sediment Geochemistry and Metal Bioavailability. Water Research, doi.org/10.1016/j.watres.2012.01.052.

Devillers D, Buzier R, Grybos M, Charriau A, Guibaud G. 2017. Key Role of the Sorption Process in Alteration of Metal and Metalloid Quantification by Fouling Development on DGT Passive Samplers. Environmental Pollution, 230:523-529. doi.org/10.1016/j. envpol.2017.07.005.

Eqani S, Kanwal A, Ali SM, Sohail M, Bhowmik AK, Ambreen A, Ali N, Fasola M, Shen H. 2016. Spatial Distribution of Dust-Bound Trace Metals From Pakistan and its Implications for Human Exposure. Environmental Pollution, 213: 213 222. DOI: 10.1016/j.envpol.2016.02.017.

Gao L, Gao B, Xu D, Liu L. 2020. DGT: A Promising Technology for in-Situ Measurement of Metal Speciation in the Environment. The Science of the Total Environment, 715:136810. DOI: 10.1016/j.scitotenv.2020.136810.

Guven DE, Akinci G. 2013. Effect of Sediment Size on Bioleaching of Heavy Metals from Contaminated Sediments of Izmir Inner Bay. Journal Environmental Science, 25:1784 94. doi.org/10.1016/s1001- 0742(12)60198-3.

Hanke G, Lepom P, Quevauviller P, Allan J, Batty J, Bignert A, Borga K, Boutrup S, Brown B, Carere M, Maagd GJ, Dominguez E, Duffek A, Glesne O, Green N, Greenwood R, Loos R, Amparo M, Andersen J, Wollgast J. 2009. Guidance Document No. 19 Guidance on Surface Water Chemical Monitoring under the Water Framework Directive.

Harper MP, Davison W, Tych W. 2000. DIFS-A Modelling and Simulation Tool for DGT Induced Trace Metal Remobilisation in Sediments and Soils. Environmental Modelling Software, 15: 55-66.

He, Y., Guo, C.S., Lv, J., Hou, S., Zhang, Y., Zhang, Y., Xu, J., 2018. Predicting Trace Metal Bioavailability to Chironomids in Sediments by Diffusive Gradients in Thin Films. Environmental Pollution, 243: 862-871.

Jitar O, Teodosiu C, Oros A, Plavan G, Nicoara M. 2015. Bioaccumulation of Heavy Metals in Marine Organisms from the Romanian Sector of the Black Sea. New Biotechnology, 32: 369- 378. doi.org/10.1016/j.nbt.2014.11.004.

Jones JI, Spencer K, Rainbow PS, Collins AL, Murphy JF, Arnold A, Duerdoth CP, Pretty JL, Smith B, Fitzherbert M, O'Shea FT, Day MC, Groves S, Zhang Y, Clarke A, Stopps J, McMillan S, Moorhouse A, Aguilera V, Edwards P, Parsonage F, Potter H, Whitehouse P. 2017. The Ecological Impacts of Contaminated Sediment From Abandoned Metal Mines. Final Report Defra Project WT0970.

Kalantzi I, Black KD, Pergantis SA, Shimmield TM, Papageorgiou N, Sevastou K, Karakassis I. 2013. Metals and Other Elements in Tissues of Wild Fish From Fish Farms and Comparison with Farmed Species in Sites With Oxic and Anoxic Sediments. Food Chemistry, 141: 680-94. doi.org/10.1016/j.foodchem.2013.04.049.
Kelderman P and Osman AA. 2007. Effect of Redox Potential on Heavy Metal Binding Forms in Polluted Canal Sediments in Delft (The Netherlands). Water Research, 41:4251-61. doi.org/10.1016/j.watres.2007.05.058.

Menegário AA., Yabuki LNM., Luko KS, Williams PN, Blackburn DM. 2017. Use of Diffusive Gradient in Thin Films for in Situ Measurements: A Review on the Progress in Chemical Fractionation, Speciation and Bioavailability of Metals in Waters. Analytica Chimica Acta, 983:54-66. doi.org/10.1016/j.aca.2017.06.041.

Mutlu E, Demir T, Yanık T, Şutan NA. 2016. Determination of Environmentally Relevant Water Quality Parameters in Serefiye Dam Turkey. Fresenius Environmental Bulletin, Vol. 25, No. 12a, Pp. 5812-5818.

Mutlu E. 2019. Evaluation of Spatio-Temporal Variations in Water Quality of Zerveli Stream (Northern Turkey) Based on Water Quality Index and Multivariate Statistical Analyses. Environmental Monitoring and Assessment, 3;191(6):335. doi: 10.1007/s10661-019-7473-5. PMID: 31049701.

Mutlu E, Kurnaz, A. 2018. Assessment of physico - chemical parameters and heavy metal pollution in Celtek Pond Water. Indian Journal of Geo-Marine Sciences 47(6):1185-1192.

Mutlu, E, Uncumusaoğlu A. 2017. Investigation of the water quality of Alpsarı Pond (Korgun-Çankırı). Turkish Journal of Fisheries and Aquatic Sciences, 17: 1231-1243

NOAA (National Oceanic and Atmospheric Administration), 1999. Screening quick reference tables (SquiRTs) https://response.restoration.noaa.gov/sites/default/files/SQui RTs.pdf (date of access:10.01.2021)

Oğuz TC. 2015. Common Water Quality Problems in Drinking Water Treatment and Solution Suggestions for Treatment, Master Thesis, Ministry of Forestry and Water Affairs, Ankara, Turkey.

Paller MH, Harmon SM, Knox AS, Kuhne WW, Halverson NV. 2019. Assessing Effects of Dissolved Organic Carbon and Water Hardness on Metal Toxicity to Ceriodaphnia Dubia Using Diffusive Gradients in Thin Films (DGT). Science Total Environment, 697, 134107.

Peng JF, Song YH, Yuan P, Cui XY, Qiu GL. 2009. The Remediation of Heavy Metals Contaminated Sediment. Journal of Hazardous Materials, 161:633-40. doi.org/10.1016/j.jhazmat.2008.04.061.

Rougerie J, Barros RM, Buzier R, Devillers D, Fondanèche P, Lissalde S, Leblanc J, Saüt M, Rebillard J, Mazzella N, Guibaud G. 2021. Diffusive Gradients in Thin Films (DGT): A Suitable Tool for Metals/Metalloids Monitoring in Continental Waterbodies at the Large Network Scale. The Science of the Total Environment, 754, 142147.

Rump HH, Krist H. 1988. Laboratory Manual for the Examination of Water, Waste Water and Soil. Second Edition. Weinheim, New York, Cambridge.

Sun HR, Gao B, Gao L, Xu DY, Sun K. 2019. Using Diffusive Gradients in Thin Films (DGT) and DGT-İnduced Fluxes in Sediments Model to Assess the Dynamic Release of Copper in Sediment Cores from the Three Gorges Reservoir, China. Science Total Environment, 672, 192-200.

Tokatli C, Ustaoğlu F. 2020. Health Risk Assessment of Toxicants in Meriç River Delta Wetland, Thrace Region, Turkey. Environmental Earth Science, 79: 426.

Türkmen M, Mutlu E, Zebel S, Türkmen A. 2018. Doğu Karadeniz Sahili Batlama Deresi'nde Dağılım Gösteren Bazı Balık Türlerinde Ağır Metal Birikiminin Değerlendirilmesi. Turkish Journal of Agriculture - Food Science and Technology, vol. 6, no. 7, pp. 858-0.

Uher E, Compère C, Combe M, Mazeas F, Gourlay-Francé C. 2017. In Situ Measurement with Diffusive Gradients in Thin Films: Effect of Biofouling in Freshwater. Environmental Science Pollution Research, 24: 13797-13807. https://doi.org/10.1007/s11356-017-8972-y 
Uher E, Zhang H, Santos S, Tusseau-Vuillemin MH, GourlayFrancé C. 2012. Impact of Biofouling on Diffusive Gradient in Thin Film Measurements in Water. Analitical Chemistry 84, 3111-3118. https://doi.org/10.1021/ac2028535.

URL:1https://www.tarimorman.gov.tr/SYGM/Belgeler/Ta\%C5 $\% 9 \mathrm{Fk} \% \mathrm{C} 4 \% \mathrm{~B} 1 \mathrm{n} \% 20 \mathrm{Y} \% \mathrm{C} 3 \% \mathrm{~B} 6$ netim\%20Planlar\%C4\%B1 /1)\%20YESILIRMAK\%20HAVZASI\%20TA\%C5\%9EKIN $\% 20$ Y\%C3\%96NETIM\%20PLANI.pdf (date of access:14.01.2021)

URL:2https://www.mevzuat.gov.tr/mevzuat?MevzuatNo=16806 \&MevzuatTur=7\&Mevzuat Tertip=5 (date of access:10.01.2021)

Yavuz CI, Vaizoğlu S, Güler Ç. 2013. İçme Suyunda Alüminyum. TAF Preventive Medicine Bulletin, 12(5) : 589596.

Yuan H, Yin H, Yang Z, Yu J, Liu E, Li Q, Tai Z, Cai Y. 2020. Diffusion Kinetic Process of Heavy Metals in Lacustrine Sediment Assessed under Different Redox Conditions by DGT and DIFS Model. Science Total Environment. 1;741:140418. doi: 10.1016/j.scitotenv.2020.140418. Epub 2020 Jun 24. PMID: 32886994.

Zhang H, Davison W, Knight B, McGrath S. 1998. In Situ Measurements of Solution Concentrations and Fluxes of Trace Metals in Soils Using DGT. Enviromental Science and Technology, 32:704-710. doi.org/10.1021/es9704388.
Zhang H, Davison W, Miller S, Tych W. 1995. In Situ High Resolution Measurements of Fluxes of $\mathrm{Ni}, \mathrm{Cu}, \mathrm{Fe}$ and $\mathrm{Mn}$ and Concentrations of $\mathrm{Zn}$ and $\mathrm{Cd}$ in Porewaters by DGT. Geochimica et Cosmochimica Acta, 59: 4181-4192.

Zhang H, Davison W. 1995. Performance Characteristics of Diffusion Gradients in Thin Films for the in Situ Measurement of Trace Metals in Aqueous Solution. Analitic Chemistry, 67: 3391-3400. doi.org/10.1021/ac00115a005.

Zhang H, Davison W. 1999. Diffusional Characteristics of Hydrogels Used in DGT and DET Techniques. Analytica Chimica Acta, 398: 329-340.

Zhang H, Davison W. 2015. Use of Diffusive Gradients in ThinFilms for Studies of Chemical Speciation and Bioavailability. Environmental Chemistry, 12: 85.doi.org/10.1071/ en14105.

Zhang H. 2003. DGT-for Measurements in Waters, Soils and Sediments. DGT Research Ltd, Lancaster, United Kingdom.

Zhang Y, Yang J, Simpson SL, Wang Y, Zhu L. 2019. Application of Diffusive Gradients in Thin Films (DGT) and Simultaneously Extracted Metals (SEM) for Evaluating Bioavailability of Metal Contaminants in the Sediments of Taihu Lake, China. Ecotoxicology and Environmental Safety, 184:109627. DOI: 10.1016/j.ecoenv.2019.109627. 